Z. Klin. Chem. Klin. Biochem.

13. Jg. 1975 , S. $273-276$

\title{
Serum Dopamine $\beta$-Hydroxylase: Assay and Enzyme Properties
}

\author{
By E. S. Markianos and Irene E. Nyström
}

Neıırochemische Abteilung der Psychiatrischen Klinik der Universität München

(Eingegangen am 8. Juli/17. Oktober 1974)

Summary: A method for the estimation of dopamine $\beta$-hydroxylase activity in human serum is described, based on a thin layer chromatographic separation of the substrate $\left(\left[{ }^{14} \mathrm{C}\right]\right.$ tyramine $)$ from the reaction product $\left(\left[{ }^{14} \mathrm{C}\right]\right.$ octopamine). The basic properties of the human serum enzyme, investigated by this method are described.

\section{Dopamin- $\beta$-hydroxylase im Serum: Bestimmung und Eigenschaften}

Zusammenfassung: Eine Methode zur Bestimmung der Dopamin- $\beta$-hydroxylase in Serum wird beschrieben. Das Substrat, $\left[{ }^{14} \mathrm{C}\right]$ Tyramin, wird dünnschichtchromatographisch vom Produkt, $\left[{ }^{14} \mathrm{C}\right]$ Octopamin, getrennt. Die Auswertung erfolgt durch einen Dünnschichtchromatographie-Scanner. Die mit dieser Methode untersuchten Eigenschaften des Enzyms werden beschrieben.

\section{Introduction}

Dopamine $\beta$-hydroxylase (EC 1.14.2.1), the enzyme that catalyzes the hydroxylation of dopamine to noradrenaline, was found to be localized in the catecholamine containing vesicles of the sympathetic nerve terminals and the adrenal medulla (1). During nerve stimulation, the enzyme is released together with catecholamines $(2,3)$ and appears in the blood as circulating dopamine $\beta$-hydroxylase activity.

The enzyme hydroxylates a number of phenylethyl- . and phenylpropylamines (4). It is inhibited by a variety of chelating agents (5). The enzyme contains copper in the molecule which undergoes cyclic reduction and oxidation during the hydroxylation of the substrate $(5,6)$. Recently, dopamine $\beta$-hydroxylase was found to be a tetrameric glycoprotein with about $4 \%$ carbohydrates and 4 . copper atoms per molecule (7).

In serum, low concentrations of copper cause a marked increase in activity (8) by removing an inhibitor. The same effect is shown by reagents that react with sulfhydryl groups. The inhibitors can build chelates with copper in situ rather than remove the metal from the enzyme (9).

Until a sensitive radioactive assay was introduced (10), methods of assay were based on the separation of the reaction product from the substrate by column chromatography. In the former, the main incubation is followed by a second one with purified phenylethanolamine-N-methyl-transferase and $\left[{ }^{14} \mathrm{C}\right] \mathrm{S}$-adenosylmethionine. The $\mathrm{N}$-methyl-phenylethanolamine formed is then extracted and counted in a scintillation counter.
A proportional release of noradrenaline and dopamine $\beta$-hydroxylase into the blood was found (11). The release occurs by exocytosis, during which a fusion of the vesicular and neuronal membrane takes place.

For the estimation of dopamine $\beta$-hydroxylase activity in nonpurified biological materials, where other enzymes acting on catecholamines are present, it is necessary to make a qualitative check of the nature of the reaction products. This was performed by using thin layer chromatographic or gas chromatographic methods for the estimation of the changes in substrate and product concentrations during the incubation.

Using $\left[{ }^{14} \mathrm{C}\right]$ tyramine as substrate for the enzyme, we applied an aliquot of the incubation mixture directly to a thin layer chromatographic plate. After development, the plate was scanned and two well separated peaks of tyramine and octopamine were obtained. Integration of the peaks gives the relative amounts of substrate and product present in the incubation mixture at the time of the application on the plate.

This direct analysis of the incubation mixture has certain advantages for the exact estimation of the enzyme activity: Any eventual byproducts can be identified, the amount of substrate still present can be controlled, the analysis can be carried out without interrupting the reaction and the estimation is independent of the volume applied to the plate. Many sources of error are thus eliminated.

\section{Materials}

$\left[2-{ }^{14} \mathrm{C} \mid\right.$ Tyramine acctate $(50 \mathrm{Ci} / \mathrm{mol})$ was obtained from $\mathrm{CEA}$ (Commissariat a l'énergie atomique), France. Catalase was obtain: 
ed from Schuchardt, Munich, Germany; octopamine from Sigma Chemical Company, U.S.A. Pre-coated Silica gel plates and the other chemicals from E. Merck, Darmstadt, Germany. Pentafluoropropionic acid anliydride for the gas chromatography was from Pierce Chemical Company, U.S.A.

\section{Methods and Results}

\section{Thin layer chromatography}

Pre-coated silica gel plates $200 \times 200 \mathrm{~mm}$ were used. The best scparation of tyramine from octopamine was achieved with a solvent consisting of chloroform, methanol, acetic acid, water (Volumes $60 \mathrm{ml}+25 \mathrm{ml}+15 \mathrm{ml}+5 \mathrm{ml}$ )

Table 1 shows the $R_{F}$ values for a number of catecholamines and their metabolites as well as tryptophan and its metabolites.

Table 2 refers to a number of enzymes which could be estimated using basically the same procedure described.

Until now, we have used this procedure successfully for the estimation of dopamine $\beta$-hydroxylase activity in serum, brain and adrenal medulla, and of tyrosine hydroxylase and tryptophan hydroxylase in brain.

Tab. 1. Thin layer chromatography of catecholamines, tryptophan and their metabolites.

\begin{tabular}{|c|c|c|}
\hline Substance & $\mathrm{R}_{\mathbf{F}}$ & Color in UV \\
\hline Tyrosine & 0.30 & blue \\
\hline Phenylalanine & 0.52 & blue \\
\hline$L$-DOPA & 0.16 & dark violet \\
\hline Dopamine & 0.38 & dark violet \\
\hline Noradrenalinc & 0.20 & violet \\
\hline Adrenaline & 0.26 & violet \\
\hline Tyramine & 0.53 & light violet \\
\hline Octopamine & 0.42 & light violet \\
\hline Metanephrine & 0.51 & blue \\
\hline Normetanephrine & 0.46 & blue \\
\hline 3-Mcthoxyty ramine & 0.58 & light violet \\
\hline 3,4-Dihy droxy phenylacetic acid & 0.68 & gray-blue \\
\hline 3-Methoxy-4-hy droxy phenylglycol & 0.77 & blue \\
\hline 3,4-Dihydroxymandelic acid & 0.89 & blue \\
\hline 3-Methoxy-4-hydroxymandelic acid & 0.45 & blue \\
\hline 4-Hydroxyphenylacetic acid & 0.89 & blue \\
\hline Homovanillic acid & 0.94 & blue \\
\hline Homovanillic alcohol & 0.96 & dark violet \\
\hline Tryptophan & 0.45 & light violet \\
\hline 5-Hydroxy tryptophan & 0.23 & dark violet \\
\hline 5-Hydroxy tryptamine & 0.46 & brown \\
\hline $\mathrm{N}$-acetyl-5-hydroxy tryptamine & 0.78 & violet \\
\hline 5-Hydroxy-indolacetic acid & 0.98 & dark violet \\
\hline
\end{tabular}

\section{Assay of serum dopamine $\beta$-hydroxylase}

The incubation mixture contained in a volume of $0.15 \mathrm{ml}$ : citratc-phosphatc buffer pH 4.80, $0.124 \mathrm{~mol} / 1$; ascorbate 2.0 $\mathrm{mmol} / \mathrm{l}$; fumarate $60 \mathrm{mmol} / 1$; pargyline $10 \mu \mathrm{mol} / \mathrm{l}$; catalase 250 units; copper sulfate $25 \mu \mathrm{mol} / 1 ;{ }^{14} \mathrm{C}$ ) tyramine $50 \mu \mathrm{mol} / 1$. The ascorbate and fumarate solutions were adjusted to $\mathrm{pH} 5.20$.

To this mixture, $50 \mu \mathrm{l}$ serum were added and incubated at $37^{\circ} \mathrm{C}$ for 40 minutes. The amount of tyramine hydroxylated is, under these conditions, proportional to the incubation time for up to 80 minutes for the enzyme activities usually found in serum. The substrate consumption is usually about $20 \%$. $20 \mu \mathrm{l}$ of the reaction mixture are applied to a thin layer plate, developed and the plate scanned. The scanner used was the Berthold Dünnschichtscanner, Wildbad, Germany, in combination with a scaler-timer for counting the radioactivity. The dopamine $\beta$-hydroxylase activity. was expressed in $U / 1$ (micromoles tyramine hydroxylated per 1 serum and minute). A mean value of $1.015 \pm 0.570 \mathrm{U} / 1$ was found from the sera of 91 hospitalized, non-psychiatric paticnts.

Figure 1 shows the increase of the octopamine peak with the incubation time.

\section{Identification of the reaction product by gas chromato- graphy}

The second radioactivity peak that appears after incubation of $\left[{ }^{14} \mathrm{C}\right]$ tyramine with serum, has the same $R_{F}$ value as octopamine on thin layer plates.

In addition, after incubation, the incubation mix ture was freeze-dried, the methanol soluble part taken and reacted with pentafluoropropionic anhydride. After evaporation of the
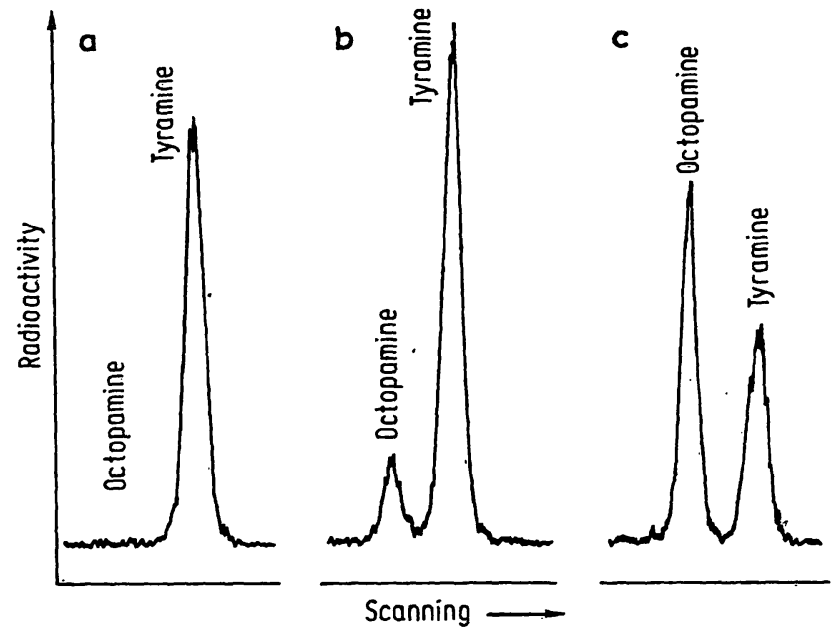

Fig. 1. Radiochromatograms of an incubation mixture for serum dopamine $\beta$-hydroxylase at time zero (a), 20 (b) and 120 (c) minutes.

Tab. 2. Enzyme activitics which can be estimated using the thin layer chromatographic method described.

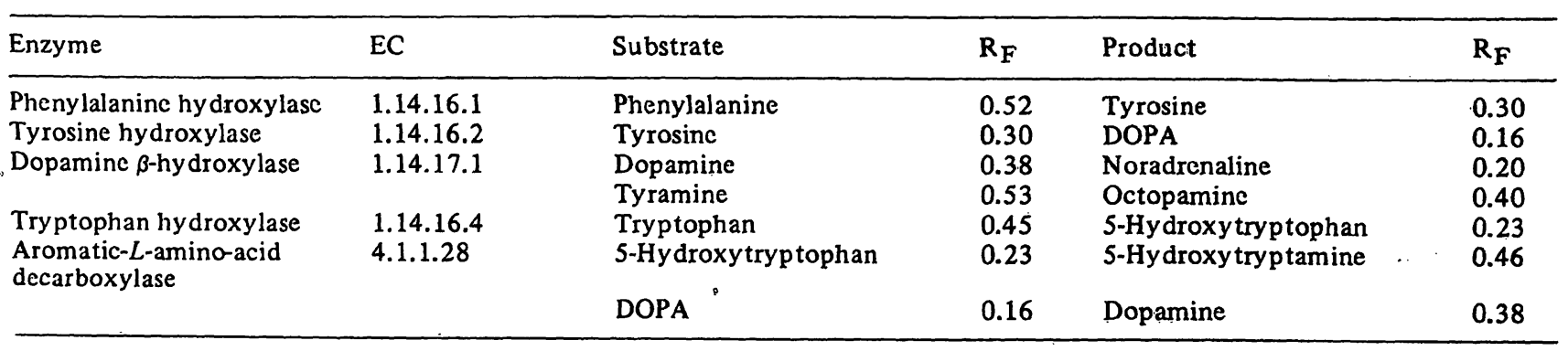


reagent, the product was dissolved in cthyl acetate (dry) and injected into a gas chromatographic system (Hewlett-Packard $7620 \mathrm{~A}$ ), with a coiled glass column 6 fect $\times 4 \mathrm{~mm}$, packed with chromosorb WAW DMCS 80-100 mesh, coated with $6 \%$ OV-17. Carrier gas flow rate $40 \mathrm{ml} / \mathrm{h}$ (helium), oven temperature (isotherm) $140^{\circ} \mathrm{C}$. Electron capture detector (nickel), tempcrature $175^{\circ} \mathrm{C}$. Argon-methane flow rate $60 \mathrm{ml} / \mathrm{h}$.

Under these conditions, the retention time was $1176 \mathrm{~s}$ for tyramine and $1320 \mathrm{~s}$ for octopamine. The pentafluoropropionic anhydride derivatives gave a good response and were stable for days.

This gas chromatographic estimation of tyramine and octopamine, could be used for the estimation of dopamine $\beta$-hydroxylase activity in cases where very small amounts of substrate are possible, without labelled substrate being necessary (e.g. experiments in vivo).

\section{pH optimum of the serum enzyme}

Figure 2 shows the relation of dopamine $\beta$-hydroxylase activity to the incubation $\mathrm{pH}$. The activity has a maximum between $\mathrm{pH} 5.2$ and 5.4. Outside this $\mathrm{pH}$ range, great variations in activity are found. This makes it necessary to check the $\mathrm{pH}$ for every incubation. In the method described, after the application on the plate, the $\mathrm{pH}$ is measured in the remaining incubation mixture using a microelectrode.

\section{pH stability of the serum dopamine $\beta$-hydroxylase}

$0.5 \mathrm{ml}$ serum were kept at $\mathrm{pH}$ between 3 and 12 for 30 minutes at $37^{\circ} \mathrm{C}$, neutralized and incubated at $\mathrm{pH} 5.2-5.4$ as usual.

The enzyme shows optimum stability at physiological $\mathrm{pH}$ and is totally inactivated under $\mathrm{pH} 4$ and over $\mathrm{pH} 11$.

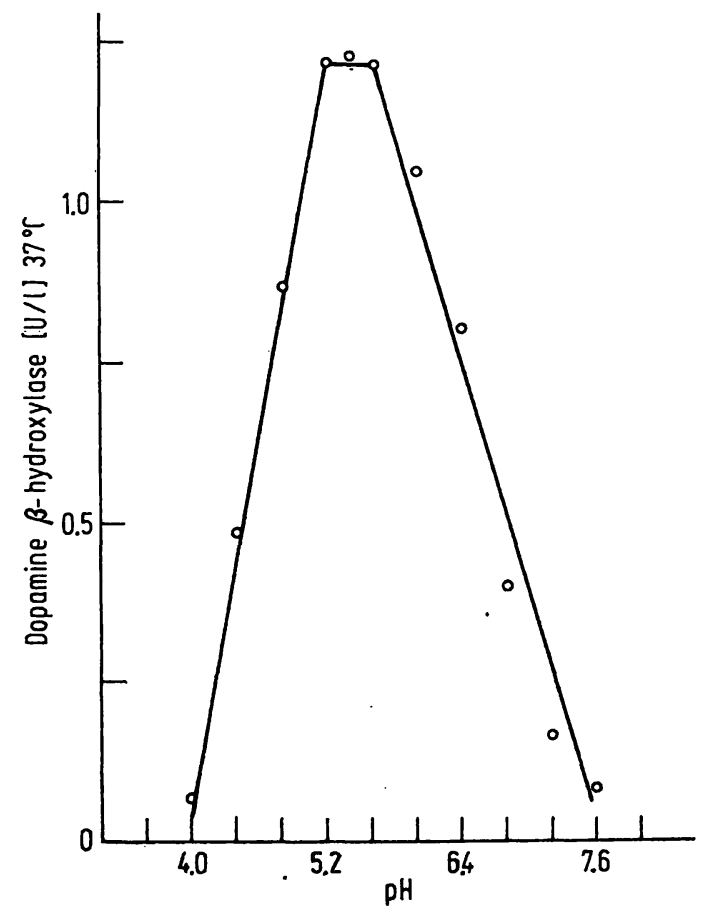

Fig. 2. pH optimum of serum dopamine $\beta$-hydroxylase activity.
The enzyme in blood, is under the conditions for its optimal stability, but is not active because of the high $\mathrm{pH}$. The serum enzyme remains idle as long as it is in the blood.

\section{Influence of copper concentration}

Figure 3 shows the dependence of the enzyme activity on the copper concentration present in the incubation mixture. Without addition of copper, a little or no activity is found. This activity increases if the serum is kept for several days at $4^{\circ} \mathrm{C}$, although the activity at $25 \mu \mathrm{mol} / \mathrm{l}$ copper remains the same, so that an inactivation of some inhibitor can be assumed.

\section{Temperature stability of the serum enzyme}

Serum was kept for 60 minutes at temperatures between $25^{\circ} \mathrm{C}$ and $68^{\circ} \mathrm{C}$ and then incubated at $37^{\circ} \mathrm{C}$ (Fig. 4).

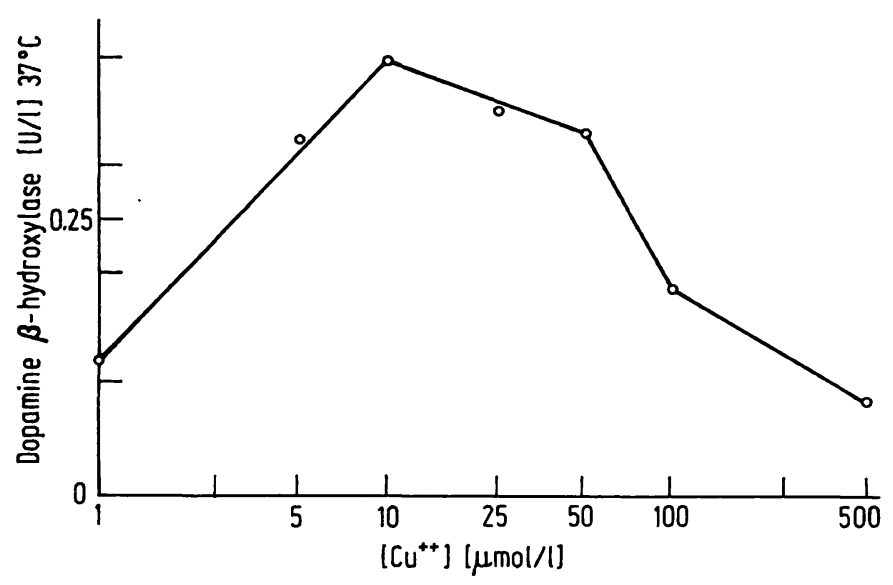

Fig. 3. Variation of serum dopamine $\beta$-hydroxylase activity with copper ions added to the incubation mixture.

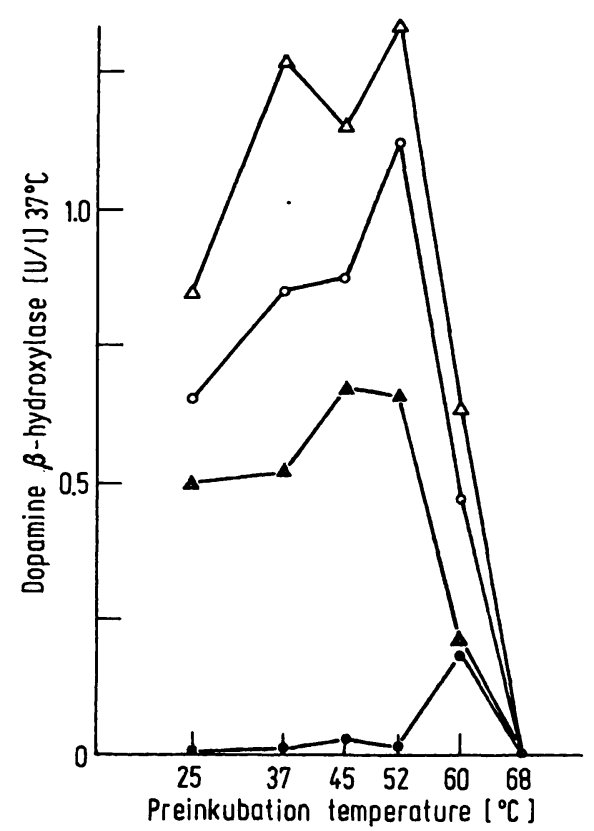

Fig. 4. Tempcrature stability of serum dopamine $\beta$-hydroxylase. $60 \mathrm{~min}$ preincubation at $25-68^{\circ} \mathrm{C}$. Activity determined at $37^{\circ} \mathrm{C}$ in the absence $(\bullet-\bullet)$ and in the presence of $5(0-0), 25(\Delta-\Delta)$ and $100(\Delta-\Delta) \mu \mathrm{mol} / 1 \mathrm{Cu}^{++}$. 
The enzyme in serum is totally inactivated only at temperatures over $60^{\circ} \mathrm{C}$. When incubated without addition of copper, activity appears in the serum kept at $60^{\circ} \mathrm{C}$, which indicates that at least some inhibitor is inactivated before the whole enzyme is inactivated. The increase in activity at $52^{\circ} \mathrm{C}$ and $5 \mu \mathrm{mol} / \mathrm{l}$ copper, is a result of the same effect.

When the incubation temperature is varied, an increase in activity is found with temperatures up to $52^{\circ} \mathrm{C}$, with a rapid fall over that temperature (Fig. 5).

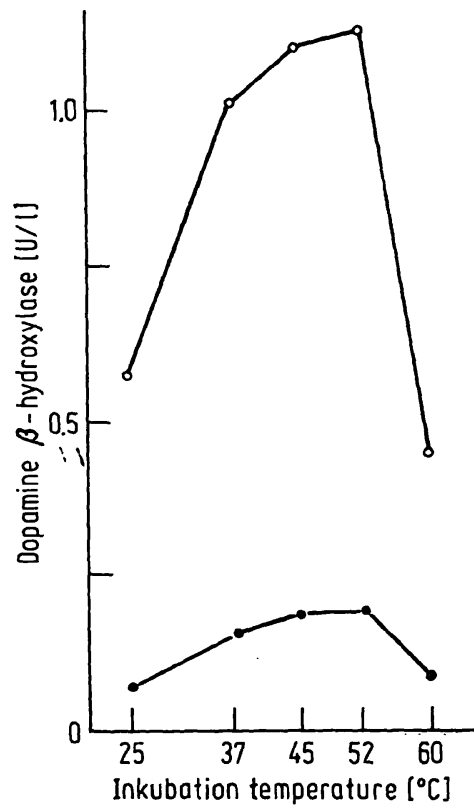

Fig. 5. Variation of serum dopamine $\beta$-hydroxylase activity with the incubation temperature $\left(\bullet-\right.$ without $\mathrm{Cu}^{++}$; ○—o with $25 \mu \mathrm{mol} / 1 \mathrm{Cu}^{++}$).

\section{Inhibitory effect of EDTA}

EDTA and other chelating agents should inhibit dopamine $\beta$-hydroxylase by forming complexes with the enzyme copper. Figure 6 shows this expected effect.

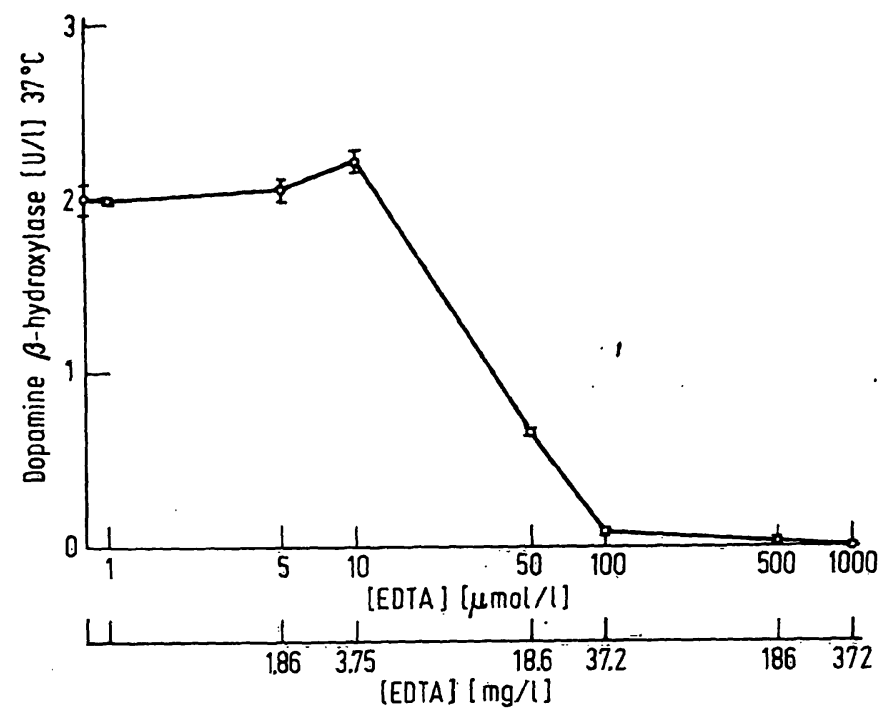

Fig. 6. Inhibition of serum dopamine $\beta$-hydroxylase by EDTA.

EDTA concentrations over $10 \mu \mathrm{mol} / \mathrm{l}$ are inhibitory for the enzyme. Thus, blood taken with addition of EDTA, cannot be used for the estimation of the dopamine $\beta$-hydroxylase activity.

\section{Discussion}

Sub-saturating substrate concentrations are used in this method, because we found it gave greater accuracy. The correlation of the activity measured at $0.05 \mathrm{mmol} / \mathrm{l}$ tyramine to that measured at $2.5 \mathrm{mmol} / 1$, tested for 18 sera, gave a linear coefficient $r=0.9694$, as determined by linear regression analysis. The dopamine $\beta$-hydroxylase activities of these 18 subjects were between 3.58 and $22.87 \mathrm{U} / \mathrm{l}$ when $2.5 \mathrm{mmol} / 1$ tyramine were used, and between 0.503 and 2.962 units when $50 \mu \mathrm{mol} / 1$ tyramine was present. The ratio of activity at $2.5 \mathrm{mmol} / 1$ substrate to activity at $50 \mu \mathrm{mol} / \mathrm{l}$ was $7.38 \pm 0.78$ (S.D.).

\section{References}

1. Kaufman, S. \& Friedman, S. (1965), Pharmacol. Rev., 17, $71-100$.

2. Oka, M., Kajikawa, K., Ohuchi, T., Yoshida, H. \& Imaizumi, R. (1967), Life Sci., 6, 461-465.

3. Hörtnagl, H., Hörtnagl, H. \& Winkler, H. (1969), J. Physiol. (London), 205, 103-114.

4. Goldstein, M. \& Contrera, J. F. (1962), J. Biol. Chem., 237, 1898-1902.

5. Goldstein, M., Lauber, E. \& McKereghan, M. R. (1965), J. Biol. Chem., 240, 2066-2072.

6. Friedman, S. \& Kaufman, S. (1965), J. Biol. Chem., 240, 4763-4773.

7. Wallace, E. F., Krantz, M. J. \& Lovenberg; W. (1973), Proc. Nat. Acad. Sci. USA, 70, 2253-2255.

8. Friedman, L. S., Ohuchi, T., Goldstein, M., Axelrod, F., Fish, J. \& Dancis, J. (1972), Nature (London), 236, 310311.

- 9. Shopsin, B., Friedman, L. S., Goldstein, M. \& Gershon, S. (1972), Psychopharmacologia (Berl.), 27, 11-16.

10. Rush, R. A. \& Geffen, L. B. (1972), Circulation Res. 31, 444-452.

11. Geffen, L. B., Rush, R. A., Louis, W. J. \& Doyle, A. E. (1973), Clinical Science, 44, 617-620.

Dr. E. S. Markianos

Psychiatrische Klinik der Universität München Neurochemische Abteilung

D-8000 München 2, Nussbaumstraße 7, Germany 